\title{
Porter's Diamond Approaches and the Competitiveness Web
}

\author{
Charis Vlados ${ }^{1}$ \\ ${ }^{1}$ Department of Economics, Democritus University of Thrace, Komotini, Greece \\ Correspondence: Charis Vlados, Department of Economics, Democritus University of Thrace, 69100, Komotini, \\ Greece. Tel: 30-253-103-9503.
}

Received: September 3, 2019

Accepted: September 10, 2019

Online Published: September 11, 2019

doi:10.5430/ijba.v10n5p33

URL: https://doi.org/10.5430/ijba.v10n5p33

\begin{abstract}
This study explores Porter's diamond of national competitiveness, by critically examining both the analytical virtues, the extensions, and the criticisms it has received over time. The aim is to analyse the stage in which the study of the diamond is currently in, about twenty years after the introduction of M. Porter, suggesting that its analytical contribution focusing on the industrial dynamics (meso-competitiveness) is still relevant even though significant analytical repositioning and improvements are possible. This research attempts to integrate a set of evolutionary socioeconomic dimensions into the "diamond's" analytical perspective, ending up with a proposed "competitiveness web" conceptual model.
\end{abstract}

Keywords: Porter's diamond, Porter's diamond extensions, Porter's diamond criticisms, Porter's diamond repositioning, competitiveness web

\section{Introduction}

Researchers who examine the problem of competitiveness approach the concept with different definitions, classifications, factors, models, and evaluation criteria. Despite all the discussions on competitiveness, there is no consensus for a well-established model of competitiveness (Balkyte \& Tvaronavičiene, 2010). Specifically, for Waheeduzzaman and Ryans (1996) competitiveness is like "beauty": the definition, measurement, and understanding of competitiveness belong to the eye of the beholder, thus reflecting the analytical "subjectivity" of the subject matter. In this sense, since there is no commonly accepted perspective of competitiveness, we understand that regardless of the type of competitiveness - at national, industrial, or firm-level (Ayob \& Senik, 2015; Berger, 2008; Ferreira, Fernandes \& Ratten, 2016; Fortes, Ratten, Barcellos \& Estevão, 2018; Moon \& Peery, 1995) — being competitive means that a socioeconomic agent performs better than its counterparts do. The agent who has higher competitiveness is the one who prevails and manages to survive and grow within the current competition circumstances.

According to Porter's "Competitive Advantage of Nations" (1990a), economic analysis requires an approach deriving from the systematic study of thriving industries at the international level. The central theme of this book is why firms established in a particular nation can create and sustain a competitive advantage against their global competitors in particular industries or industry segments (Huggins \& Izushi, 2015). Porter argues that the essential factors to competitive advantage in most of the industries - and especially those that are vital to productivity growth in advanced economies - are not inherited or endowed but are created within a nation. According to Porter, in the traditional economic analyses, the productive factors (that is, labour, land, natural resources, and capital) play the most significant role in trade flows, since a nation exports those goods that use the endowed productive factors intensively. For Porter, this endowment analysis has its roots in the works of classical political economists, which, however, is incomplete and possibly inaccurate.

Porter goes on to introduce four determinants that shape national competitiveness. In his system called "diamond," these four determinants-factor conditions, demand conditions, related and supporting industries, firm strategy-structure-rivalry — are established within a nation and operate within the particular industries.

However, it seems that Porter's focus on industries to analyse competitiveness has also led to the introduction of various criticisms. More specifically, Jacobs and de Jong (1992) conclude that the dialectical distinction between convergence and divergence of specific industries is unclear in Porter's book, which is prerequisite for developing a strategic perspective of economic sectors. According to the authors, the approaches of new technological or 
techno-economic paradigms (as defined in the evolutionary economics school; Andersen, 2009; Nelson et al., 2018) or form of regulation and accumulation regime (as defined in the French regulation school; Aglietta, 2010; Boyer, 2004; Lipietz, 1985) can enrich Porter's analysis.

According to Smit (2010), scholars usually examine Porter's theory together with the theories of trade; this gives the false impression that it is a competitive theory, although it is a framework emerged from the theory of management. The theoretical analyses of trade examine the partial national benefits from trade by dealing with them primarily as a "positive-sum game." However, this does not imply that a nation withholds absolute or competitive advantages vis-à-vis other nations. According to the author, a firm builds benefits out of competition according to its ability to have a competitive advantage over rivals, and therefore competitive advantage is a "zero-sum game." In this context, according to the author and in line with this article's perspective, by refocusing the model towards the context of the firm would probably add more value to its application in business than merely discussing it in the context of the competitive advantage of nations.

In a similar conceptual direction, Foss (1996) asserts that one constant problem in Porter's thinking is the lack of an adequate theory of the firm. Namely, Foss suggests in particular that, metaphorically, Porter has fully captured only one of the blades of the scissor of competitive advantage in his theory, where he comprehensively identifies and discusses only industry determinants of competitive advantage.

With these introductory clarifications, we are able to estimate, in a first reading, that the analytical contribution of Porter's competitive advantage of nations theory lies primarily in the systematisation of the competitiveness concept on industrial and national level (de Man, van den Bosch \& Elfring, 1997; Stonehouse \& Snowdon, 2007). By breaking apart progressively the traditional trade theory, which was hypothesising that a nation's productive factors are inherited, Porter introduces the "factor creation" element that drives nations towards competitive advantages. However, Porter's narrow focus on industries it seems to have been the subject of extensive criticism (Daly, 1993; Penttinen, 1994). It seems that one of the most common criticisms of Porter's theory is that it takes into account only the industrial determinants and, therefore, the analysis of the firm as a strategic/evolutionary creator of national competitive advantages is bypassed, at least in part. Here, therefore, lies a dimension to Porter's theory that needs possible improvements.

\section{Methodology}

In this context, therefore, it seems useful to analyse and further categorise the overall criticism into the theory of Porter's "diamond". The aim of this study is - after presenting succinctly the diamond model of industrial competitiveness of nations - to find out the present stage of development of its applications, extensions and criticisms, by proposing a repositioned conceptual perspective that can be an enrichment basis for both the study of national/industrial competitiveness and the "diamond's" analytical model.

To achieve the purpose of this research, the structure and steps of the article reflect the overall methodology:

(i) Literature review of Porter's diamond model, application examples and counter-proposed extensions and criticisms to the model;

(ii) Discussion of the critical results and introduction of an analytical and methodological counter-proposal that enriches and extends (possibly) Porter's diamond usage;

(iii) Central conclusions and limitations of the counter-proposed methodology.

\section{Literature Review}

The introduction of the diamond of national competitiveness poses the question (Porter, 1990b, p. 78): "Why are certain companies based in certain nations capable of consistent innovation? Why do they ruthlessly pursue improvements, seeking an ever more sophisticated source of competitive advantage? Why are they able to overcome the substantial barriers to change and innovation that so often accompany success?"

In this context, Porter (1990b, p. 78) suggests that (Figure 1): "The answer lies in four broad attributes of a nation, attributes that individually and as a system constitute the diamond of national advantage, the playing field that each nation establishes and operates for its industries. These attributes are:

I. Factor Conditions. The nation's position in factors of production, such as skilled labour or infrastructure, necessary to compete in a given industry.

II. Demand Conditions. The nature of home-market demand for the industry's product or service.

III. Related and Supporting Industries. The presence or absence in the nation of supplier industries and other 
related industries that are internationally competitive.

IV. Firm Strategy, Structure, and Rivalry. The conditions in the nation governing how companies are created, organised, and managed, as well as the nature of domestic rivalry."

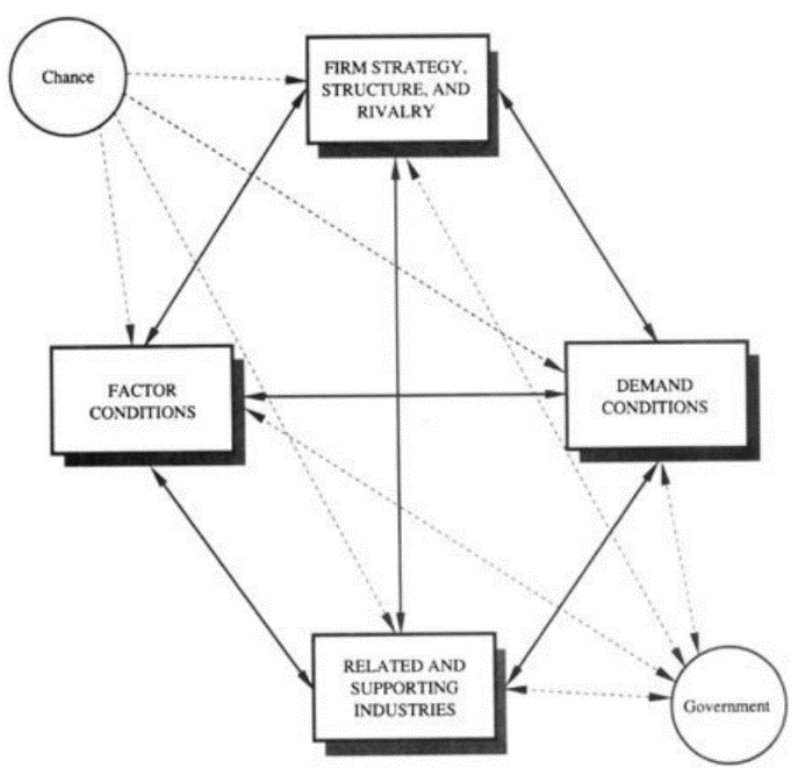

Figure 1. The complete system

Reproduced from Porter (1990a, p. 196)

Specifically, he treats each of the four attributes that constitute the diamond of national advantage as follows:

I. Concerning the factor endowment of every nation, Porter (1990a, pp. 128-129) suggests that the analysis and description of productive factors is usually conducted in a broad way (such as land, labour, and capital), which is a generalisation that cannot recognise the competitive advantages, from a strategic perspective, of particular industries. In this context, the factors can be grouped into several broad categories: Human resources, physical resources, knowledge resources, capital resources, and infrastructure.

Next, Porter (1990b, p. 79) suggests that: "In the sophisticated industries that form the backbone of any advanced economy, a nation does not inherit but instead creates the most important factors of production."

II. With demand conditions, Porter (1990a, pp. 143-161) states that home demand shapes the rate and character of improvement and innovation by a nation's firms. In this context, he recognises three significant broad attributes of home demand: (a) the composition (or nature of buyer needs) of home demand, (b) the size and pattern of growth of home demand, and (c) the mechanisms by which a nation's domestic preferences are transmitted to foreign markets:

a. Regarding home demand composition, he argues that this shapes the way firms perceive, interpret, and respond to the needs of buyers.

b. About the size of demand and the growth pattern, these can reinforce national advantages in a specific industry, given that the composition of demand is sophisticated and covers not only domestic but also international needs.

c. For internationalisation of the domestic demand, he claims that constitutes the third way in which home demand conditions contribute to national advantage, through mechanisms by which a nation's domestic demand internationalises and pulls a nation's products and services abroad.

III. Regarding the related and supporting industries, Porter (1990a, pp. 162-166) argues that the presence in a nation of internationally competitive supplier industries offers competitive advantages in downstream industries since they provide more effective and direct access to more cost-effective inputs. About related 
industries, he supports the idea that the presence of related competitive industries can often lead to the creation of new competitive industries. In particular, related industries are those in which firms can coordinate or share activities in the value chain when competing or those that involve complementary products—such as computers and applications software.

IV. About firm strategy, structure, and rivalry, Porter (1990a, pp. 170-180) conveys the idea that the domestic pattern of rivalry plays a profound role in the process of innovation and, therefore, international success. Concerning the strategy and structure of domestic firms, he claims that national circumstances affect how firms are managed and how they choose to compete. In this context, by arguing that sharp differences exist within and among nations in the goals that firms seek to achieve, there are four distinct categories of goals: company goals, goals of individuals, the influence of national prestige/priority on goals, and the goals of firms and individuals that are reflected in the nature of the commitment of capital and human resources to an industry, to a firm, and, for employees, to a profession.

In conclusion, in this diamond system, another two external determinants are added: the role of chance and the role of government:

V. With the role of chance, Porter (1990a, pp. 191-192) argues that chance constitutes external events in a nation, while national firms and governments do not have the necessary power to influence these occurrences. In this context, Porter highlights some examples of chance that influence the national competitive advantages, such as major technological discontinuities, shifts in global financial markets or exchange rates, surges of international or regional demand, political decisions by foreign governments, wars.

VI. With respect to the role of government, Porter (1990a, pp. 194-195) states that even though it is tempting to make government the fifth determinant, this is not the most useful way to understand government's role in international competition: government's real role in national competitive advantage is in influencing the four determinants. He suggests in particular that governments can affect factor conditions through subsidies, policies oriented towards capital markets, and policies for education, while the role of government to shape local demand conditions is usually more subtle. Notably, national governments act as carriers that establish product standards at the local level or regulations that direct the needs of buyers, while he notices that the government is often a significant buyer of many products in a nation. In this context, a government can reshape the conditions under which related or supporting industries operate, such as control of advertising media or regulation of supporting services. Finally, the governmental policy can affect the structure and strategy of firms, through measures and mechanisms such as capital market regulations, tax policy, and antitrust laws.

To operationalise this diamond of six determinants, Porter articulates 16 industry "clusters" and tests empirically the model presenting the results of specific national industry studies. Porter assesses the overall pattern of national competitive advantage in eight of the ten nations included in the study: West Germany, Italy, Japan, South Korea, Sweden, Switzerland, the United Kingdom, and the United States; Porter does not report Denmark and Singapore. For each of the eight industries, Porter analyses their industries into 16 clusters, grouping them into four "upstream" clusters, six clusters for industries and supporting sectors, and six clusters for final consumption of goods and services. The four "upstream" clusters include Materials and Metals, Forest Products, Petroleum and Chemicals, and Semiconductors and Computers. The six "industry and supporting" sector clusters consist of Multiple Business, Transportation, Power Generation and Distribution, Office, Telecommunications, and Defence. The six industry clusters for "final consumption expenditure" consist of Food and Beverages, Textiles and Apparel, Housing and Household, Health Care, Personal, and Entertainment and Leisure.

Finally, the diamond theory of national competitive advantages is supplemented with the analysis of four stages of national competitive development. According to Porter (1990a, pp. 661-672), these successive stages correspond to the following situations and conditions:

I. Factor-driven: This is the initial stage of economic development, where virtually all internationally successful industries in the nation draw their advantage almost solely from basic factors of production, whether they are natural resources, favourable growing conditions for certain crops, or an abundant and inexpensive semi-skilled labour pool.

II. Investment-driven: The national competitive advantage in this stage of development depends on the ability of a nation and the domestic firms to invest aggressively. The domestic firms in this stage of development invest in constructing modern, and usually large-scale, facilities by utilising the most advanced technology offered in the 
global market.

III. Innovation-driven: In this stage of development, the "full diamond" takes place since a broad array of industries participates. As shown in Figure 2, all the determinants of the diamond operate at the same time, having a strong interaction and contributing to the national competitive advantage.

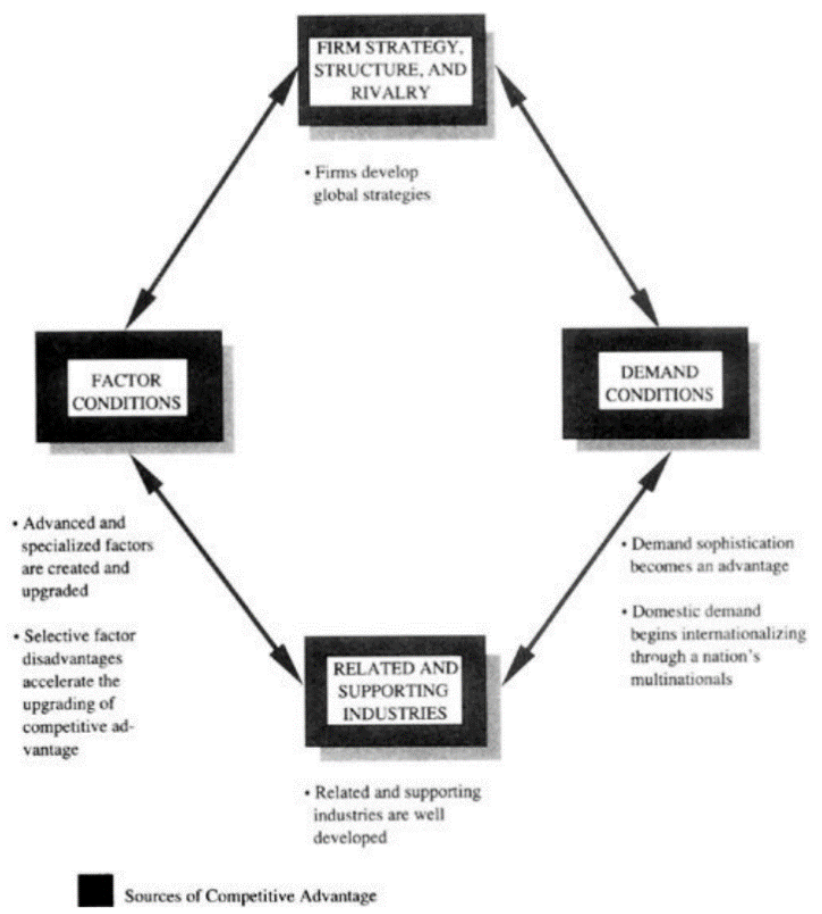

Figure 2. The Innovation-driven economy

Reproduced from Porter (1990a, p. 669)

IV. Wealth-driven: National economies pass through these three first development stages if they manage to sustain their competitive industrial advantages dynamically. The process of upgrading the competitive advantages involves an ever-increasing sophistication of an increasing number of industries in which domestic firms participate and compete. In the process, positions in less advanced, lower productivity segments are lost. The wealth-driven stage is, in contrast, one that leads to decline ultimately. The driving force in a wealth-driven economy is the achieved wealth. According to Porter, the problem is that the motivations of investors, managers, and individuals shift in ways that undermine sustained investment and innovation, and hence upgrading.

Overall, the analytic basis of Porter's diamond lies in the evolutionary comprehension of industrial competitiveness, although understood in a given and "pure" national context. In this direction, Porter's approach asserts that competitive advantages in a nation do not emerge in any "mechanistic" or automatic way since the particular history plays a significant role. Porter's analysis makes clear the dynamic and evolutionary character of national advantages. These are constructed and reconstructed through "idiosyncratic" processes that acquire different content and form according to the national and industrial contexts. Porter suggests that any nation passes through its historical process of development. The mix of industries a nation can host and the unique trajectory is able (or not) to cross through the diamond's stages of development, reflect the "sui generis" diamond conditions can shape. In this direction, it is essential to study the history that incubated national development since it carves the particular factors providing national competitive advantages.

Moreover, it seems that Porter's diamond has seen growing popularity over time (alternating between acceptance and rejection or criticism) as perhaps the most essential methodological framework of national competitiveness analysis. Below, there are some indicative examples of applications of “industrial” studies that use Porter's framework within 
the national competitiveness context:

- Bellak and Weiss (1993) present a cluster analysis of Austria, a small and open economy, arguing that an application of Porter's methodology involves several problems (data, measurement, service industries) in the Austrian context. They identify a poor treatment by Porter of foreign investment, technology and service industries, and the significance of particular clusters to a nation's competitiveness.

- Öz (2001, p. 135) explores the sources of competitive advantage of Turkish construction companies in international markets by using Michael Porter's diamond framework. The author concludes that this study challenges a "common approach that attributes Turkish contractors' success in international markets to labour cost advantages and geographic and cultural proximity to several promising markets." Specifically, by applying the diamond framework, it seems that "Turkish contractors' advantages are found not to be limited to 'factor conditions' and 'chance' events. There are other essential advantages behind their success, such as the existence of a dynamic home market, favourable entrepreneurial variables, and pressures to upgrade stemming from intense domestic rivalry. The analysis also points to the areas in which they face troubles, including problems induced by the government, financing difficulties, and the weak international position of the Turkish design engineering and consultancy services industry."

- Subsequently, Öz (2002) applies Porter's diamond framework to identify the sources of international competitive advantage to Turkey in order to understand the competitive structure of the Turkish industry. The article concludes that the diamond framework can work in a developing country setting, suggesting that there are some areas in the framework - especially domestic rivalry and the role of government - where one or more of the Turkish case studies contradict the Porter hypothesis.

- Chobanyan and Leigh (2006, p. 147) examine the shape of the "Armenian National Diamond" and argue that: "despite possible limitations, the diamond framework provides a valuable starting-point for analysing appropriate development policies in emerging markets such as Armenia." They indicate that Armenia's industries currently exploit "general basic factor advantages" and that future development requires the exploitation of more advanced and specialised factor conditions along with the necessary related and supporting industries, together with appropriate demand conditions and increased competitive rivalry among firms in Armenia.

- In turn, Stone and Ranchhod (2006) apply a quantitative measurement to Porter's diamond in order to determine the competitive advantages of the UK, USA, and BRIC nations. Porter's diamond is developed further by the application of economic ratios and statistics and other indicative metrics, creating a quantitative approach to Porter's theories. Their results indicate that the UK is currently the most competitive nation and that China will soon position itself as a truly competitive one.

- Aghdaie, Seidi, and Riasi (2012) attempt to determine the barriers to Iran's saffron export to international markets by using the diamond framework. They find that only the factor conditions are not essential barriers to Iran's saffron export.

- Chung (2016, p. 257) evaluates logistics cluster competitiveness among six Asian countries based on Porter's diamond model determinants. After developing assessment criteria of logistics cluster competitiveness based on the diamond's determinants, the author calculates each weight by AHP method (Analytic Hierarchy Process) and finds that there is a significant difference in logistics cluster competitiveness among six Asian countries. According to the author, "these research results intend to provide logistics policy makers with some strategic recommendations, and may serve as a baseline for further logistics cluster studies using Porter's diamond model."

- In addition, Tsiligiris (2018) adapts Porter's diamond model as an analytical framework to evaluate the "transnational education host countries" in terms of attractiveness for exporting higher education. After conducting a pilot study for China and Malaysia and using indicative metrics for the four determinants of Porter's diamond, the author finds that China and Malaysia are both suitable transnational education host countries for expanding existing and developing new activities.

Overall, beyond the above application cases (Byun \& Mann, 2011; Dögl, Holtbrügge, \& Schuster, 2012; Harzing \& Giroud, 2014; Kharub \& Sharma, 2017), it is clear that the use of "diamond's" analytical methodology to date is both broad and multifaceted (Afzal, Lawrey, \& Gope, 2019; Fang, Zhou, Wang, Ye, \& Guo, 2018; Wonglimpiyarat, 2017). Nevertheless, various criticisms and extensions are also present.

The model of Porter's diamond seems not to satisfy a significant number of scholars over time. Below, we present 
some of the most important criticisms to the model over time as well as proposed extensions:

- In one of the earliest critiques, Rugman (1991) and Rugman and D'Cruz (1993) suggest that Porter's home-base diamond model of international competitiveness is seriously flawed when applied to a small, open, trading economy like Canada's. Such economies are highly interdependent with one or more of the triad economies-the U.S., Japanese and European. A "double diamond" framework as a "North American diamond" for Canada is proposed, which is highly integrated with the US, stating that once individual Canadian managers and workers perform to North American standards, they can take the next step to perform at global standards (Figure 3).

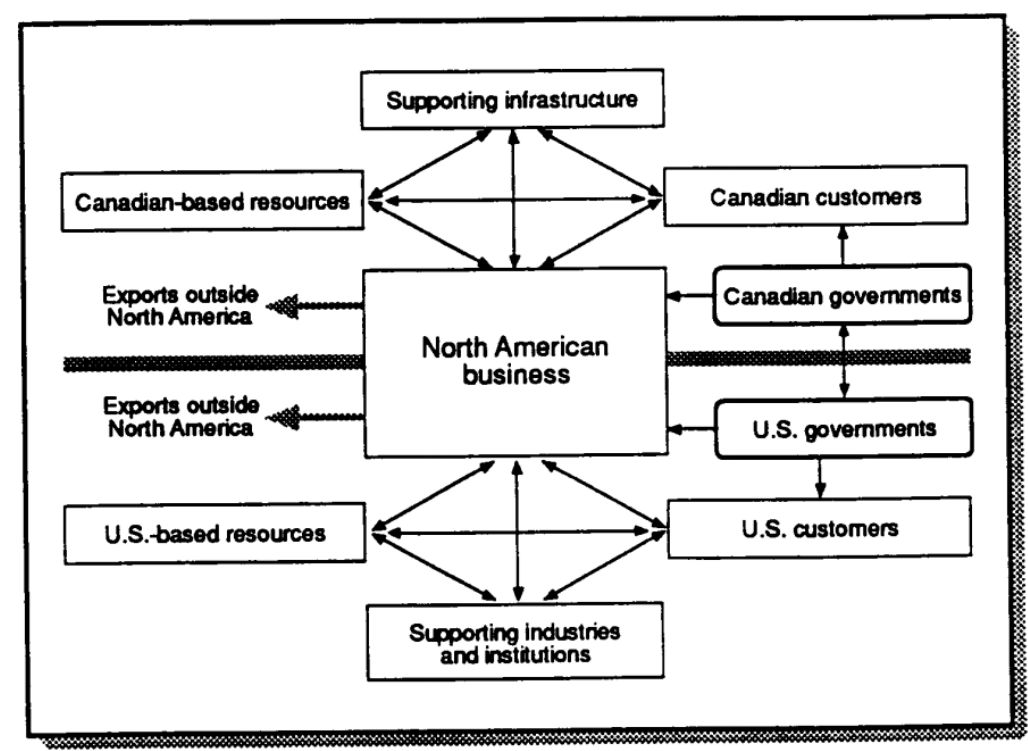

Figure 3. The North American Diamond helps Canadian businesses to become globally competitive

Reproduced from Rugman and D’Cruz (1993, p. 34)

- Grant (1991, p. 535) argues that: “Porter's analysis of the impact of national environment on international competitive performance demonstrates the potential for the theory of competitive strategy to rescue international economics from its slide into refined irrelevance, while simultaneously broadening the scope of the theory of competitive strategy to encompass both the international dimension and the dynamic context of competition. Nevertheless, the breadth and relevance of Porter's analysis have been achieved at the expense of precision and determinacy. The author suggests that the concepts are often ill defined, the theoretical relationships poorly specified, and the empirical data chosen selectively and interpreted subjectively."

- According to Rugman (1992), contrary to Porter's thinking, there is no particular reason why a multinational firm needs a home base, especially in the era of globalisation. In this context also, Dunning (1992; 1993) adds the "transnational business activity" in Porter's diamond system, suggesting that foreign inward and outward direct investment affect the diamond of competitive advantage. According to the author, "transnationality" confers unique characteristics and brings a distinctive impact on resource allocation and usage. He also notes that the evidence set out in Porter's review suggests that the significance of the industries in which the industrialised nations are seeking to promote their competitive advantages is sufficiently noteworthy for the transnational business variable to be considered as a separate factor affecting the configuration of those advantages (Figure 4). 


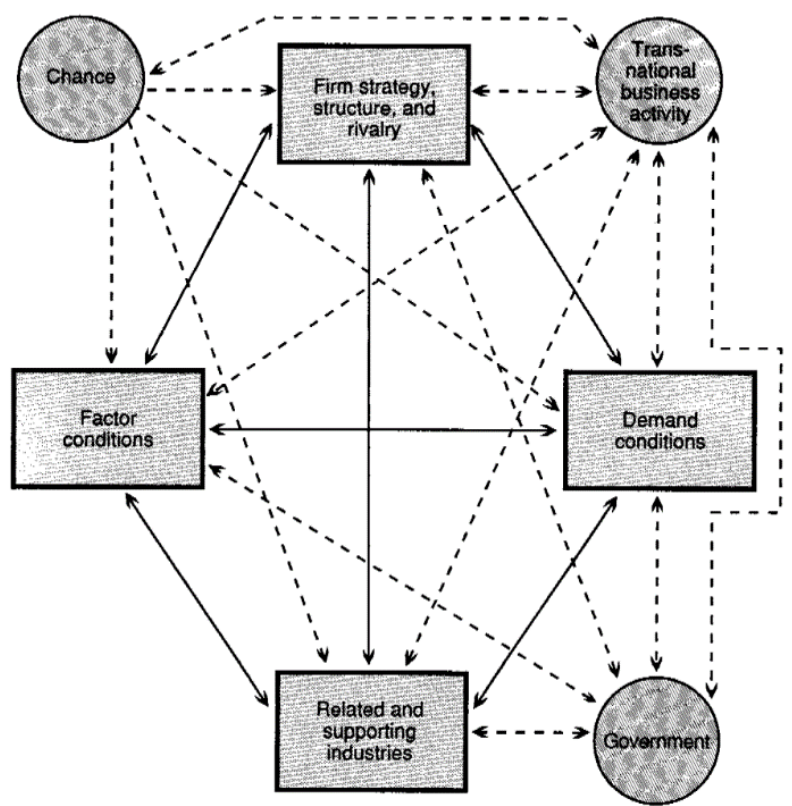

Figure 4. The complete system, according to Dunning

Reproduced from Dunning (1992, p. 140)

- Van Den Bosch and Van Prooijen (1992) argue that national culture is given little attention in the diamond model of competitive advantages. They argue that the national diamond is not exogenous to the firm and, therefore, firms have to upgrade their home base actively by amplifying their home base advantages and offsetting home-based disadvantages. In the authors' view, national culture, the base on which the national diamond rests, is nevertheless exogenous to the firm.

- Yetton, Craig, and Davis, (1992, p. 118), after reviewing how Porter's model can be applied to Canada, New Zealand, and Australia, conclude that, first, Porter has not provided a national competitive advantage theory, but a theory analysing the competitive advantage of national firms and industries, "though even the emphasis on nations (physical proximity) is progressively watered down." Second, the proof is absent in the original work and subsequent studies which results probably from the design of the study that emphasises description over validation (the data does not support the theory). Third, they suggest that Porter's theory does not deal with dynamics, that is, "how new successful firms emerge and what might be done to encourage this."

- Rugman and Verbeke (1993, pp. 296-297) suggest operationalising Porter's diamond by using a variant of SWOT analysis. According to the authors, all the factors considered as critical by Porter can be operationalised through a SWOT-analysis, therefore allowing a consistent and homogeneous managerial approach to each determinant. They also suggest that: "Porter's exclusive focus on national determinants of global competitive success may turn the attention of managers and public policy makers away from the need to monitor international threats and opportunities, as well as the requirement to build up strengths and reduce weaknesses in foreign nations." They conclude that: "such an inward diversion of focus, in the long run, would serve neither the affected firms or industries nor the home nations involved."

- Cartwright (1993) by examining New Zealand's case in terms of Porter's diamond concludes that Porter's approach is biased in terms of industry selection towards those that export from a home base and against those that compete more through investment in offshore production and value-adding. The author concludes that there is a "Multiple Linked Diamond" if determinants established offshore are added; according to the author, Porter did not objectively analyse these determinants.

- Narula (1993, p. 105) argues that Porter's competitive development model is static, based only on a subjective analysis of a few industrialised countries. The author proposes a revised framework by stressing the role of technology and international business in competitive development. He suggests that technology is an endogenous variable, resulting from both factor conditions, demand conditions, firm characteristics and supporting and related clusters, and a cause of them (Figure 5). The author concludes "that economic growth is a 
function of the rate of innovation and the national technological advantage, and that it is affected by the international trade and investment activities of firms." He asserts that: "this also includes the shifting and transfer of resources and technology to and from other countries in the process of structural adjustment as a response to economic growth." Narula underlines how "such international activity can act towards consolidating or weakening competitive advantage" and that "structural adjustment also refers to the acquisition and mastery of new technologies by the firms of a country and this occurs through technology transfer enabled through direct investment or arms-length technology sales."

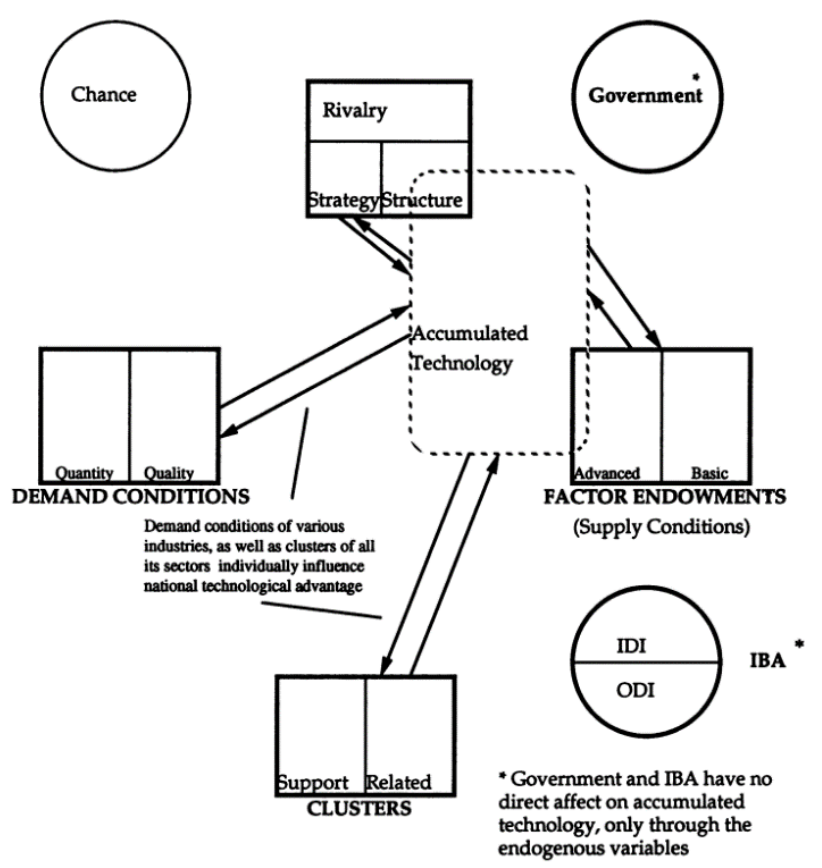

Figure 5. Development of national technological advantage: the role of accumulated technology

Reproduced from Narula (1993, p. 92). IBA stands for International Business Activity, IDI for Inward Direct Investment, and ODI for Outward Direct Investment

- Cho (1994, p. 22) extends Porter's model into a nine-factor diamond model. According to the author, there are "four physical determinants of international competitiveness, namely endowed resources, the business environment, related and supporting industries, and domestic demand." The author also notes that there are also "four human factors, namely workers, politicians and bureaucrats, entrepreneurs, and professional managers and engineers." The author concludes that external chance events should be noted as the ninth factor (Figure 6). In this context, the author also extends Porter's stages of economic development, by evaluating the life cycle of national competitiveness, by judging the influence that the nine factors may have. According to Cho (1994, pp. 24-25), "A nation's economic status is determined by its international competitiveness and the nine factors have varying weights as a country moves from a less-developed stage to a developing stage, then to a semi-developed stage, and finally to a developed stage." In this way, the life cycle of national competitiveness is determined by the characteristics prevalent in each stage and the primary sources of competitive advantage at each juncture (Figure 7). 


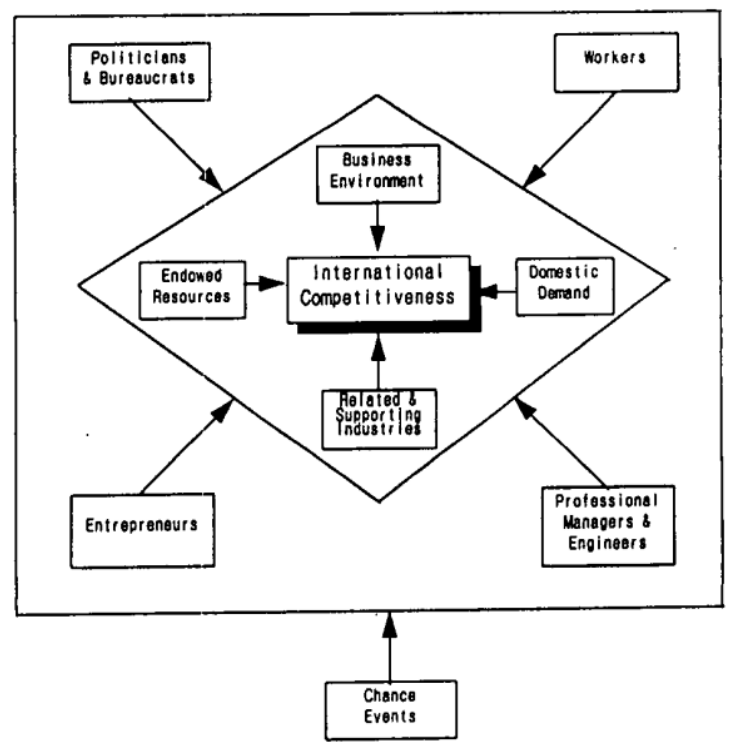

Figure 6. Cho's paradigm of international competitiveness

Reproduced from Cho (1994, p. 21)

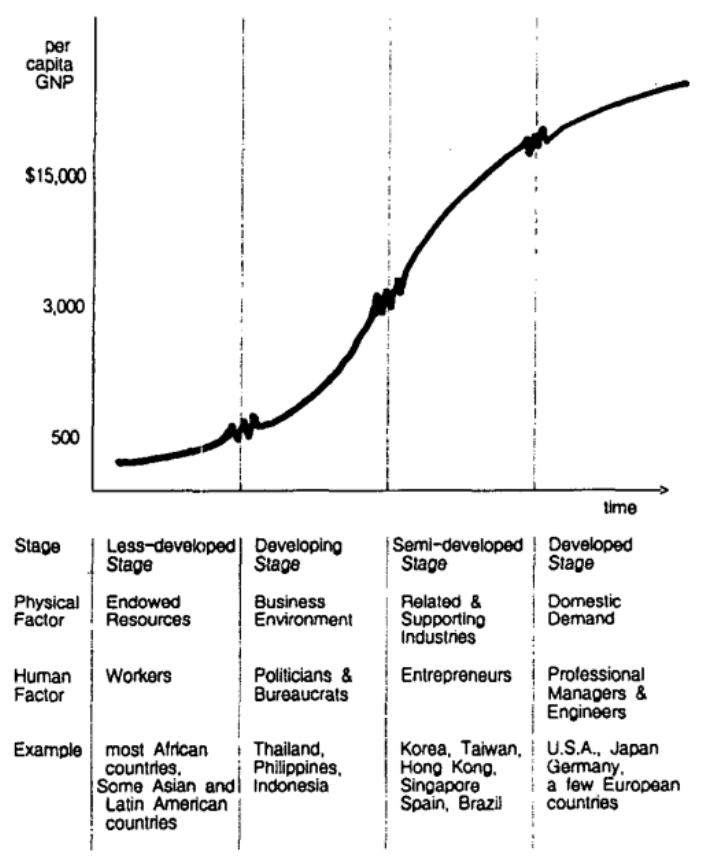

Figure 7. The life cycle of international competitiveness

Reproduced from Cho (1994, p. 25)

- O'Shaughnessy (1996, p. 19) argues that Porter's diamond “ignores some of the critical determinants of competitive advantage, his thesis of competitive advantage never transcends economics and, therefore, encourages the belief that problems are soluble exclusively through economic policy measures." The author argues finally that this is an imperfect view because "it neglects the role of history, politics, and culture in determining competitive advantage."

- Brouthers and Brouthers (1997, pp. 53) examine three variations of the diamond to determine the competitive 
advantage of The Netherlands, as a small European country. By using three models, that is, the Home-Diamond recommended by Porter, the Double-Diamond recommended by Rugman, and the Multiple-Diamond recommended by Dunning, Cartwright, and others, they find that "for small countries the Double-Diamond and Multiple-Diamond methods of calculating a country's competitive advantage are superior to Porter's Single-Diamond method." Brouthers and Brouthers (1997, pp. 66-67) conclude that: "for large developed nations the Home-Diamond would suffice while for other nations a Double or Multiple-Diamond does a better job of creating competitive advantage." Lastly, they argue that: "Dunning's MNE factor may also serve a useful function by helping to explain the relationship between the Diamond and the individual firm and in that way move the diamond approach to a level where it might become part of a strategic planning process for multinational firms."

- Moon, Verbeke, and Rugman (1995), Moon, Rugman, and Verbeke (1998), and Jin and Moon (2006) suggest that Porter fails to incorporate the effects of multinational activities, considering mainly the impact of traditional home-based activities. They propose the generalised double diamond model which formally incorporates multinational activity, where national competitiveness depends partly on the domestic diamond and partly on the "international diamond" relevant to its firms. In practice, according to Moon et al. (1998, p. 138), in the generalised double diamond, "the outside one represents a global diamond and the inside one a domestic diamond. The size of the global diamond is fixed within a foreseeable period, but the size of the domestic diamond varies according to the country size and its competitiveness. The diamond of dotted lines, between these two diamonds, is an international diamond which represents the nation's competitiveness as determined by both domestic and international parameters. The difference between the international diamond and the domestic diamond thus represents international or multinational activities. The multinational activities include both outbound and inbound foreign direct investment." They conclude that this approach, instead of Porter' diamond, can more easily operationalise the competitiveness paradigm, while the comparison of the sizes and shapes of the domestic and international diamonds reveals significant strategic differences. Lastly, this model includes the government not as an exogenous factor, but as an essential variable, which influences the four determinants of the diamond model (Figure 8).

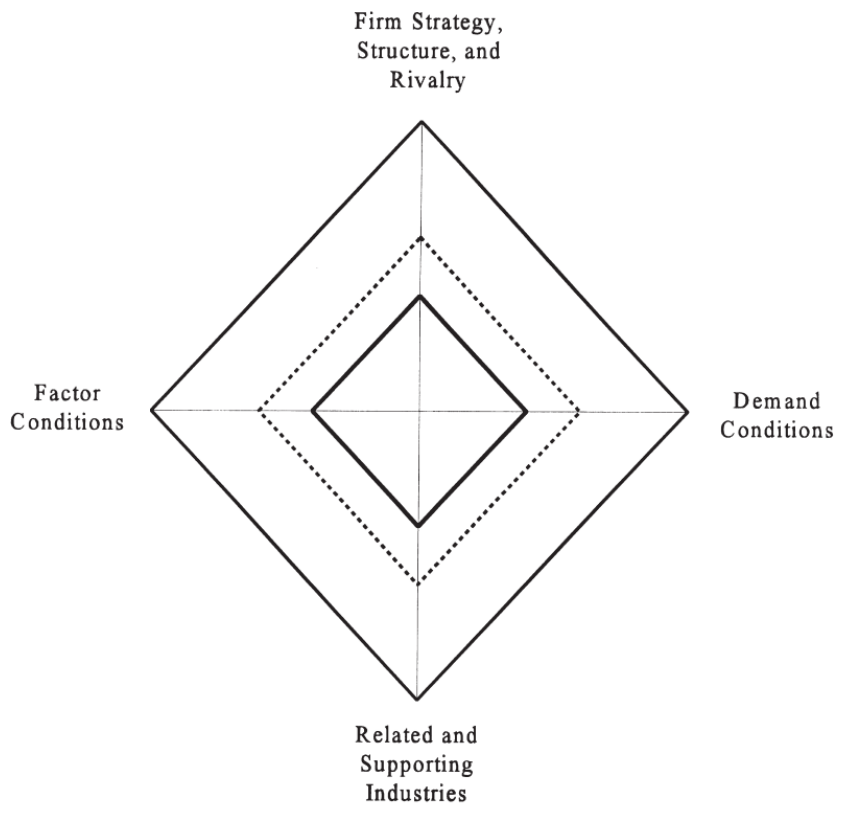

Figure 8 . The generalised double diamond

Reproduced from Moon et al. (1998, p. 138)

- According to Davies and Ellis (2000, p. 1209), there are three conclusions to be made about the conceptualisation, methodology, and robustness of Porter's competitive advantage of nations theory. The first is 
between competitiveness construed as productivity and competitiveness construed as the market share held by a subset of industries. They note in particular that "Porter began by opting for the former interpretation but then shifted back and forth between the two, making assertions based on one (prosperity depends on competitiveness qua productivity) while investigating the other (competitiveness qua market share depends upon strong diamonds). As a nation's prosperity does not depend upon the market share of a sub-set of industries, investigating the basis for market share could not elucidate the basis for prosperity." The second elision that they find out is "between the nation construed as the people in one place and the nation construed as the firms for whom that place is the home base. While Porter's central concern was to explain the prosperity of the nation in the first sense, the analysis was conducted in terms of the second so that the conclusions drawn do not lie where they are placed. The prosperity of the people in a place is not dependent upon the activities of the firms for whom that place is the home base." They also underline that a further confusion arose from the interpretation of competitive advantage as a similar concept to comparative advantage: whereas the first is concerned to explain how firms in an industry compete with each other while the second is concerned with which industries a location should have.

- Cho and Moon (2000) examine the evolution of competitiveness theory (Figure 9) starting with international trade theory, as formulated by Adam Smith, who argued that endowments set wealth. They consequently analyse Porter's competitiveness theory, which supports that choices create wealth. They finally examine the two distinct methods of measuring competitiveness presented annually by the international institutes IMD and WEF, by counter-proposing the nine-factor diamond model (Cho, 1994) as a novel and more accurate method of measuring competitiveness.

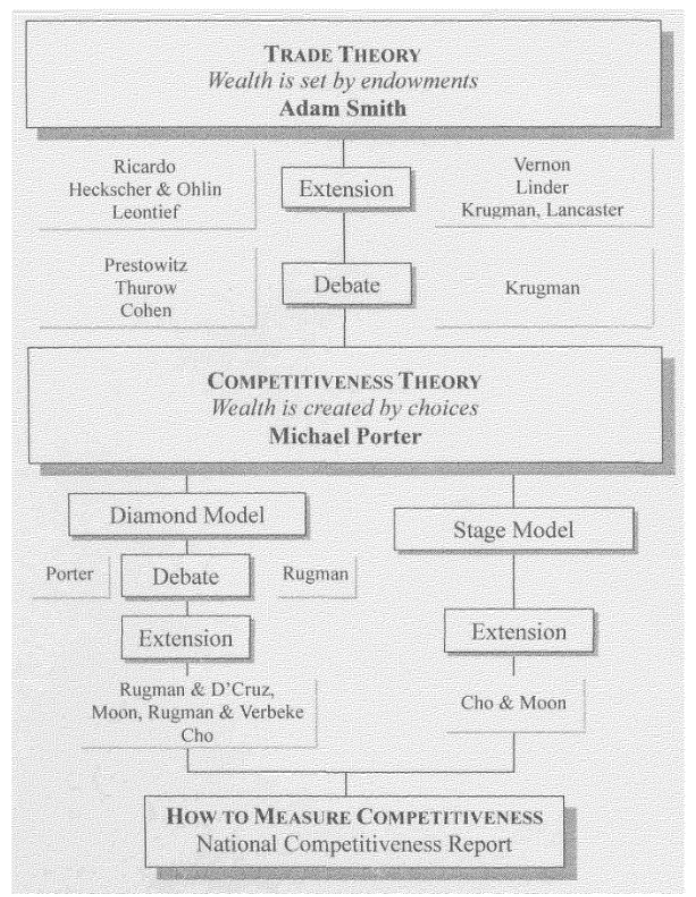

Figure 9. The evolution from trade theory to competitiveness theory

Reproduced from Cho and Moon (2000, p. xvii)

- Tavoletti and te Velde (2008, p. 316) explore how the Dutch can be the world's leaders in the flower business when they lack comparative advantage in the traditional Ricardian/Classical economic thinking of factor endowment? The authors argue that Porter's model does not explain how the four determinants of his diamond "combine to create self-reinforcing conditions in which a nations firm succeed internationally." Moreover, especially, "the evolutionary stand of the model does not explain why factor conditions (comparative advantages) are sometimes drivers and sometimes obstacles (see also the study of Waverman, 1995)." They conclude that the 
key findings of the Dutch case are that "comparative advantages and competitive advantages are not opposed, but they reinforce each other."

- Cho, Moon, and Kim (2009) argue that in the era of globalisation, multinational corporations have to analyse the country-specific advantages thoroughly in order to thrive in the global competition. Therefore, they introduce the "dual double diamond" model to analyse country-specific advantages. They find that the "generalised double diamond" and "nine-factor" models have better explanatory power than Porter's diamond when assessing country-specific advantages of countries with high international connectivity and high human-factor dependency, and that the "dual diamond" is more comprehensive than the "generalised double diamond" and "nine-factor" models in explaining country-specific advantages of countries with heterogeneous attributes (Figures 10 and 11).

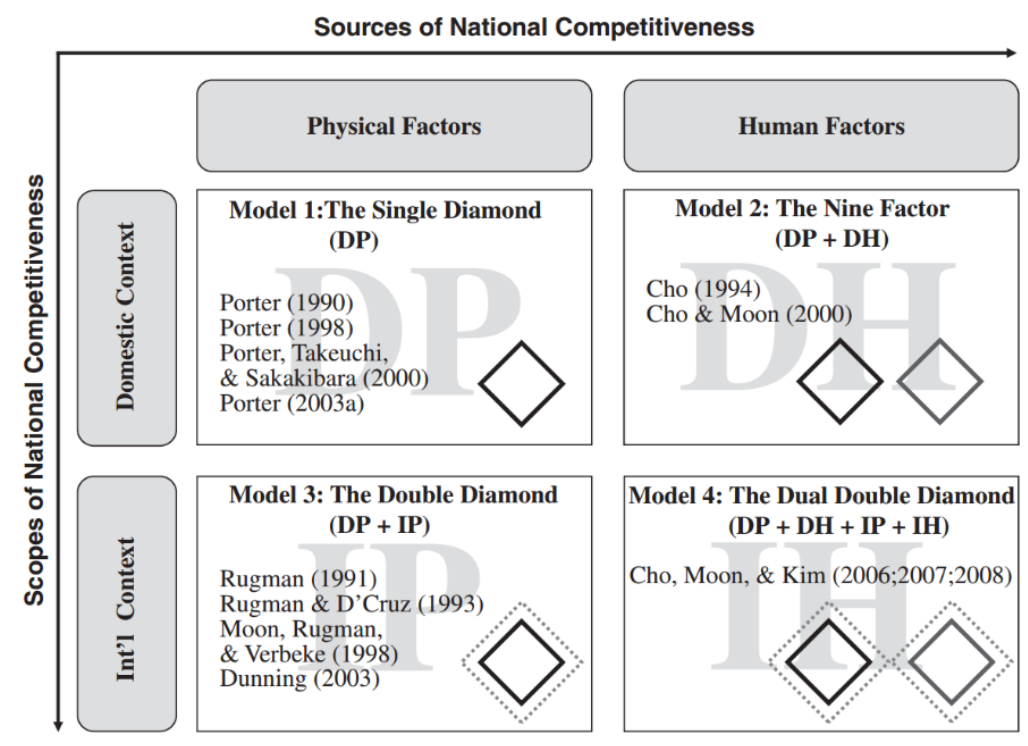

Figure 10. Porter's diamond model and its extension models

Reproduced from Cho et al. (2009, p. 88). *DP: domestic physical factors, DH: domestic human factors, IP: international physical factors, IH: international human factors

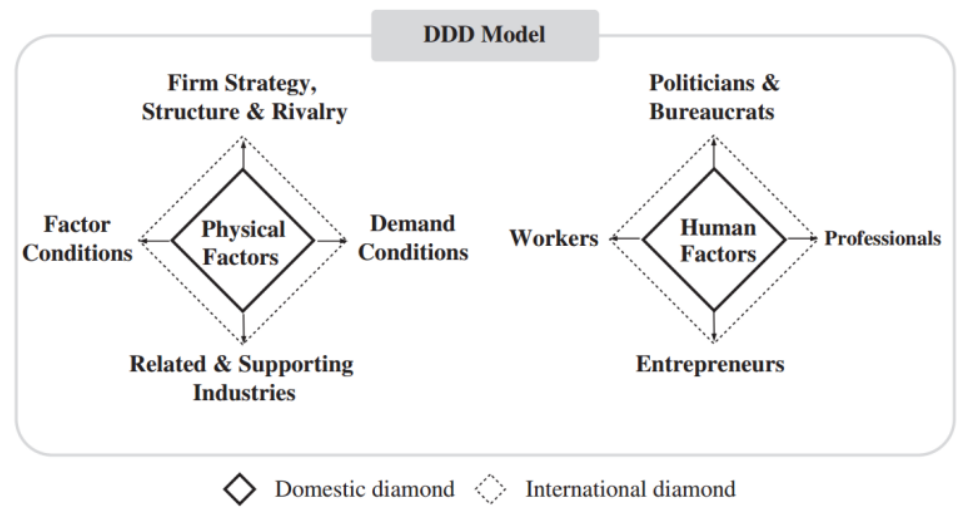

Figure 11. The dual double diamond model (DDD)

Reproduced from Cho et al. (2009, p. 89)

- Astarlığlu (2012) proposes a relationship between generic firm strategies and export performance of a company. The author treats the diamond framework as the moderator variable between firm strategies and their export 
performances. The factor of chance is eliminated from the moderator list because it is neither controllable nor predictable (Figure 12).

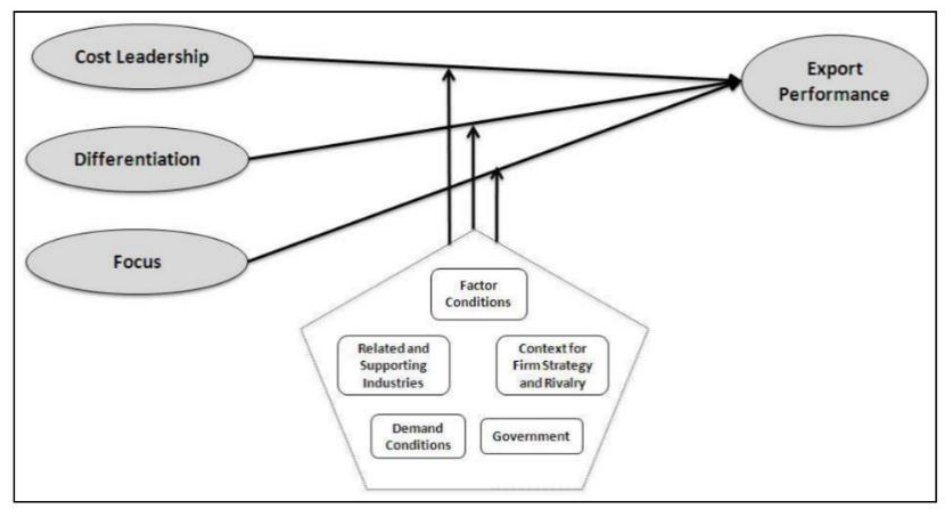

Figure 12. The diamond framework as the moderator variable in-between firm strategies and their export performances

Reproduced from Astarlığlu (2012)

- Fainshmidt, Smith, and Judge (2016, p. 81) “examine Porter's diamond model in conjunction with multinational enterprise (MNE) penetration and governance quality as a system of elements that collectively affect national competitiveness." By utilising a fuzzy-set analysis of 90 nations' data, they "identify four configurations sufficient for high national competitiveness, all of which exhibit high governance quality as a core condition." They also underline that in these four configurations, "the extent of MNE penetration is either absent or does not matter, and strength in all diamond model elements is neither necessary nor sufficient for high national competitiveness." They end up pointing out that uncovering these patterns allows a more comprehensive theoretical framework that emphasises public governance and how "elements of the diamond model, governance quality, and MNE penetration combine as complements or substitutes to affect national competitiveness."

\section{Critical Results and Analytical Counter-Proposal}

According to the criticisms that Porter's diamond model has received, this article can initially draw some general conclusions:

1) It seems that the majority of the critique's body focuses on the home-based nature of the model that, as supported by several arguments, does not define sufficiently the activity of multinational enterprises, the foreign direct investment and, more broadly, the globalised nature of industries in the contemporary business world (Bellak \& Weiss, 1993; Brouthers \& Brouthers, 1997; Cartwright, 1993; Cho et al., 2009; Dunning, 1992, 1993; Moon et al., 1998; Narula, 1993; Rugman, 1991, 1992; Rugman \& D'Cruz, 1993).

2) Criticism in the model can also be found in its inadequacy to include how successful firms emerge and which policies can be favourable in this direction (Yetton et al., 1992) or how the strengths and weaknesses of firms play a role in national competitiveness (Rugman \& Verbeke, 1993).

3) At the same time, a severe criticism to the model is whether it includes elements of national culture (Van Den Bosch \& Van Prooijen, 1992) and human factors, except the physical factors that the model takes into account (Cho, 1994).

4) Finally, to a lesser extent, there are criticisms about the historical aspect that the diamond model of national competitiveness can incorporate (O'Shaughnessy, 1996), as well in the relationship of the model with the role of governmental quality in enhancing national competitiveness (Fainshmidt et al., 2016).

With these in mind, some aspects can act as starting points for further deepening the model.

I. The diamond does not deal with the surrounding socioeconomic space comprehensively in order to systematise all the environmental levels. In diamond's analysis, critical dimensions seem to be bypassed, such as the demographics and environmental dynamics, the cultural dynamics, the technological dynamics, and the broader 
macro-level perception of the economic system.

II. The diamond does not explicitly mention nor implicates the individual firms (micro-environment) nor their broader macro-environment analytically: it is a relatively narrow "meso-environment" analytical approach. It does not also link any analytical approach of PEST type. At the same time, and in terms of analysing business strategies and micro-competitiveness is relatively inadequate, while also the traditional macro-competitiveness elements appear to be underused in the model. In this context, by not taking into account the specific socioeconomic spatial dimensions, the diamond seems to bypass the dialectic between evolutionary divergence and convergence among different socioeconomic systems in globalisation (Jacobs \& de Jong, 1992).

III. Concerning chance, it is rather clear that this poses a rather unnecessary analytical dimension since it is fundamentally self-evident in every approach - chance always exists, in every kind of socioeconomic reality. The developmental history of each socio-economic space must have more analytical emphasis (Freeman, 2019; Vlados, Deniozos, Chatzinikolaou \& Demertzis, 2018). On the other hand, the government should not be analysed only as an external and secondary factor. On the contrary, it is now clear that government policy and intervention - on every level - is, in fact, one of the most critical pillars of socioeconomic space competitiveness, and especially of national competitiveness; see, for example, the subject of helix theory of triple "academia-firms-government" relationships (Carayannis \& Campbell, 2012; Etzkowitz \& Leydesdorff, 2000).

IV. Finally, it seems that we can further valorise the diamond in terms of the competitive advantage of regions (see, for example, the EU's regional competitiveness index: Annoni, Dijkstra \& Gargano, 2017), exploiting the logic of clusters (Porter, 2000; Vicente, 2018) and business ecosystems (Iansiti \& Levien, 2004; Moore, 1997) within the "space-time defined" socioeconomic space that receives investment-development interest.

Based on the above, this article counter-proposes an analytical enlargement and enrichment of Porter's diamond into a "competitiveness web" approach. The diamond, sufficiently redirected, can look like the following illustration-a web of individual socioeconomic environments - which initiates activity from the central firm level of the system (Figure 13).

\section{The competitiveness web}

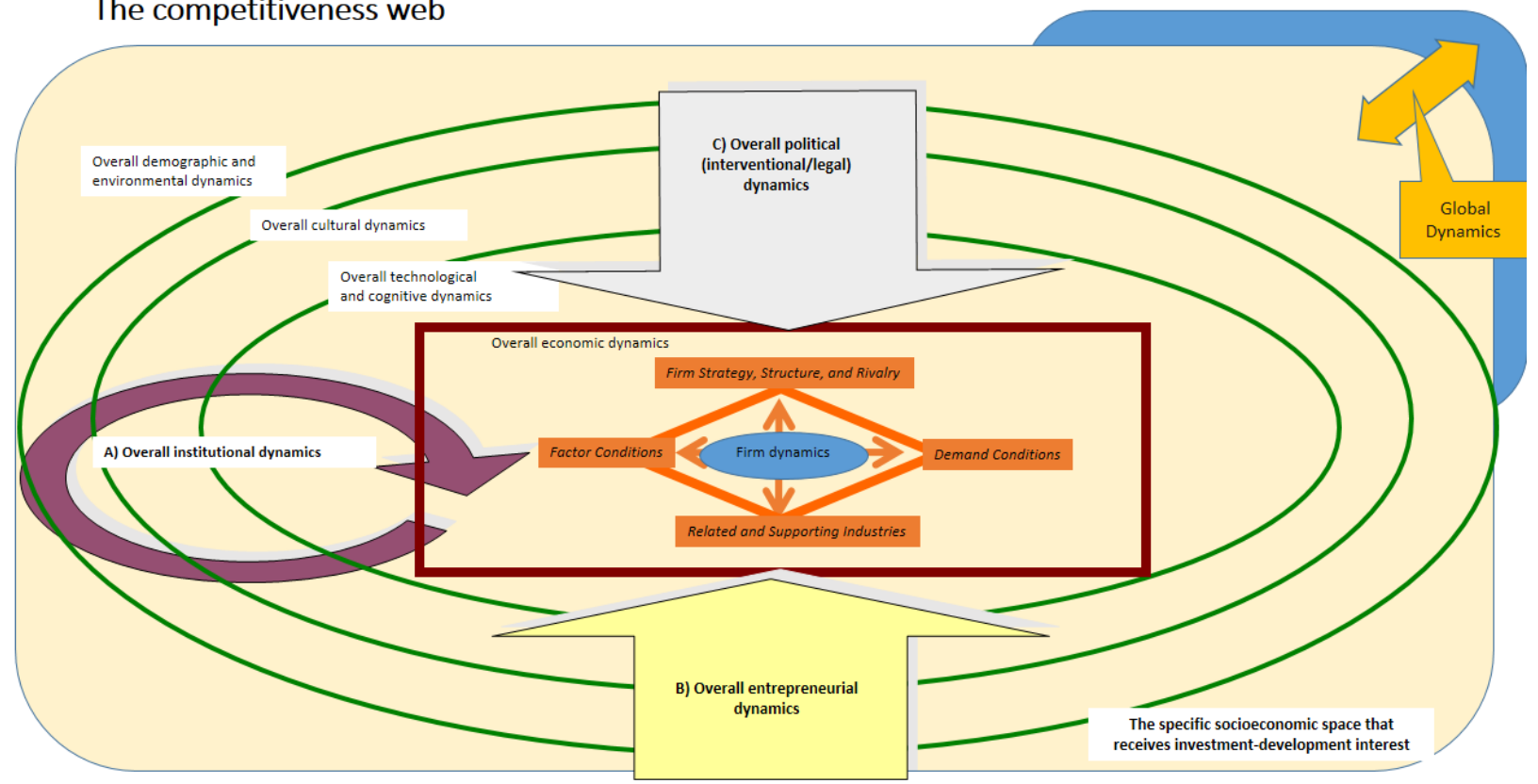

Figure 13. The web of competitiveness: The socioeconomic space that receives investment-development interest Based on $\mathrm{B} \lambda \alpha \dot{\delta} \delta \mathrm{o}$ (2006)

The "competitiveness web" is a more comprehensive framework of competitiveness analysis that can systematically 
examine all these evolutionary levels of the socioeconomic framework as an active web of factors: as an integrated system where every change of a subsystem necessarily causes changes on all other subsystems thus generating multiplicative phenomena and evolutionary feedbacks. The movement and change of each systemic level affect the movement of others, and each change of a factor reshapes the evolutionary dynamics of the others.

The structure of this integrated system of the competitive environment is defined by three analytical spheres:

A. The particular institutional "physiognomy" of each spatially established socioeconomic formation that assimilates all the actions. Within this sphere of analysis, it is possible to understand the critical importance of the partial spatially established socioeconomic systems as "pools of advantages" for the entrepreneurial action they incorporate within the dynamics of globalisation. This analytical sphere includes in the form of successive and dialectically interdependent subsystems, from the upper to lowest and vice versa:

I. The overall demographic and environmental dynamics

II. The overall social dynamics

III. The overall technological and cognitive dynamics

IV. The overall economic dynamics

B. The firms' actions articulated within the system;

C. The public-governmental intervention which contributes to the creation and reproduction of the system.

On the one hand, the actions of private entrepreneurship and, on the other hand, the actions of state intervention are the two major structural spheres that continuously reorganise the system of reproduction of the socioeconomic formations that host the economic activity. Moreover, within this constant reorganisation, both these structural actors (the private and public sphere) acquire specific content, form and define, at the same time, their co-evolving trajectories.

This analytical scheme can find scope on every spatial level (local, national or international) in a unifying way - potentially exploiting the analytical virtues of the "double diamond" as well as the particular "peripherality." It can also effectively assimilate the examination of global dynamics, which restructures all the partial spatially established socioeconomic systems systematically, on all sides, defining their competitive dynamics.

With this kind of understanding, the analysis of competitiveness can ultimately acquire a solid evolutionary perspective and clarify the continuous dynamic synthesis between the actions of firms, the state (more broadly, the public intervention) and each spatially established social formation; this synthesis is the source for the construction of competitiveness and all the development trajectories within globalisation.

\section{Conclusions and Limitations}

In conclusion, the "Diamond" model can be particularly useful in analysing competitiveness within globalisation. Especially, with an extended systemic recast -in the context of the counter-proposed "Competitiveness Web"-it could be an effective method of comprehending competitiveness uniformly: from the macro- to the micro-level of competitiveness, through the meso-environment, bearing a steadily evolutionary and historical perspective.

The counter-proposed methodology of "competitiveness web" manages to:

(A) Incorporate the connection between Porter's diamond dimensions and critical extra-economic dimensions (demographic, environmental, cultural, technological and cognitive dynamics) that uninterruptedly feed (and fuelled by) the four central factors of Porter's diamond.

(B) Introduce in diamond's analysis the surrounding economic dynamics' context (macro-competitiveness) that encompasses Porter's diamond dimensions: it concerns the surrounding macroeconomic environment, which in practice defines (and redefines) the nature and dynamics of diamond's dimensions.

(C) Place at the diamond's centre the capitalist firm's evolutionary dynamics (micro-competitiveness), whose strategic, technological, and managerial choices and actions (Vlados, 2004, 2005; Vlados, Katimertzopoulos, \& Blatsos, 2019), determine the specific morphology and dynamics of the diamond's dimensions interactively.

(D) Integrate the surrounding institutional plexus that defines dialectically all the previous interdependent and hierarchically systemic components.

(E) Introduce the surrounding political dynamics (the interventional and legal content) as internal, endogenous, and essential co-creation axis of the diamond's factors. 
(F) Take into account also the surrounding (cross-industrial) entrepreneurial dynamics as a fundamental, structural axis of the system's evolutionary trajectory.

(G) Place the diamond model in a spatial analysis context that broadens its analytic usability, by overcoming the narrow national level of analysis and enabling the cross-spatial activation of the model: from local to national, and from regional to international level.

(H) Integrate diamond's analysis into the surrounding global dynamics' context, where the different spatially established socioeconomic systems interact systematically: the global systemic interactions cross transversely and redefine the partial systems evolutionarily, at all levels concurrently.

Of course, the proposed "competitive web" model of this first approach requires necessary further processing in the future in order to obtain a fuller sense that can give operational usability and control over its interpretative and predictive capacity in the field.

\section{Acknowledgements}

The author wants to show his gratitude to the following colleagues. First, Dimos Chatzinikolaou, Doctoral Student at the Department of Economics of the Democritus University of Thrace, for his work on translating, editing, and adding the citations, of this manuscript. Second, Dr Andreas Andrikopoulos, Associate Professor at the Department of Business Administration of the University of the Aegean, who provided useful comments during the writing of this manuscript.

\section{References}

Afzal, M., Lawrey, R., \& Gope, J. (2019). Understanding national innovation system (NIS) using porter's diamond model (PDM) of competitiveness in ASEAN-05. Competitiveness Review: An International Business Journal, 29(4), 336-355. https://doi.org/10.1108/CR-12-2017-0088

Aghdaie, S. F. A., Seidi, M., \& Riasi, A. (2012). Identifying the barriers to Iran's saffron export by using Porter's Diamond Model. International Journal of Marketing Studies, 4(5), 129-138. https://doi.org/10.5539/ijms.v4n5p129

Aglietta, M. (2010). La crise: Le Voies de Sortie (Nouv. éd). Paris: Michalon.

Andersen, E. S. (2009). Schumpeter's Evolutionary Economics: A theoretical, Historical and Statistical Analysis of the Engine of Capitalism. London, New York: Anthem Press.

Annoni, P., Dijkstra, L., \& Gargano, N. (2017). The EU Regional Competitiveness Index 2016. Luxemburg: EU Publications Office.

Astarlıoglu, M. (2012). Moderating effect of Porter's diamond framework between firm strategies and export performance: A conceptual model. LAÜ Sosyal Bilimler Dergisi, 3(2), 35-64.

Ayob, A. H., \& Senik, Z. C. (2015). The role of competitive strategies on export market selection by SMEs in an emerging economy. International Journal of Business and Globalisation, 14(2), 208-225. https://doi.org/10.1504/IJBG.2015.067436

Balkyte, A., \& Tvaronavičiene, M. (2010). Perception of competitiveness in the context of sustainable development: Facets of "sustainable competitiveness". Journal of Business Economics and Management, 11(2), 341-365. https://doi.org/10.3846/jbem.2010.17

Bellak, C. J., \& Weiss, A. (1993). A note on the Austrian “diamond”. Management International Review; Wiesbaden, 33(2), 109-118.

Berger, T. (2008). Concepts of national competitiveness. Journal of International Business and Economy, 9(1), 13-17.

Boyer, R. (2004). Théorie de la régulation: Les fondamentaux. Paris: La Découverte.

Brouthers, K. D., \& Brouthers, L. E. (1997). Explaining national competitive advantage for a small European country: A test of three competing models. International Business Review, 6(1), 53-70. https://doi.org/10.1016/S0969-5931(96)00036-4

Byun, S., \& Mann, M. (2011). Accessing opportunities in apparel retail sectors in India: Porter's diamond approach. Journal of Fashion Marketing and Management: An International Journal, 15(2), 194-210. https://doi.org/10.1108/13612021111132636 
Carayannis, E. G., \& Campbell, D. F. J. (2012). Mode 3 Knowledge Production in Quadruple Helix Innovation Systems: 21st-Century Democracy, Innovation, and Entrepreneurship for Development. New York: Springer-Verlag. https://doi.org/10.1007/978-1-4614-2062-0

Cartwright, W. R. (1993). Multiple Linked "Diamonds" and the international competitiveness of export-dependent industries: The New Zealand experience. MIR: Management International Review, 33, 55-70.

Cho, D. S., \& Moon, H. C. (2000). From Adam Smith to Michael Porter: Evolution of Competitiveness Theory. New Jersey, London, Singapore, Hong Kong: World Scientific. https://doi.org/10.1142/9789812385222

Cho, D. S., Moon, H. C., \& Kim, M. Y. (2009). Does one size fit all? A dual double diamond approach to country-specific advantages. Asian Business \& Management, 8(1), 83-102. https://doi.org/10.1057/abm.2008.27

Cho, D.-S. (1994). A dynamic approach to international competitiveness: The case of Korea. Asia Pacific Business Review, 1(1), 17-36. https://doi.org/10.1080/13602389400000002

Chobanyan, A., \& Leigh, L. (2006). The competitive advantages of nations: Applying the "Diamond" model to Armenia. International Journal of Emerging Markets, 1(2), 147-164. https://doi.org/10.1108/17468800610658316

Chung, T. W. (2016). A study on logistics cluster competitiveness among Asia main countries using the Porter's diamond model. The Asian Journal of Shipping and Logistics, 32(4), 257-264. https://doi.org/10.1016/j.ajs1.2016.12.010

Daly, D. J. (1993). Porter's diamond and exchange rates. Management International Review; Wiesbaden, 33(2), 119-134.

Davies, H., \& Ellis, P. (2000). Porter's competitive advantage of nations: Time for the final judgement?. Journal of Management Studies, 37(8), 1189-1214. https://doi.org/10.1111/1467-6486.00221

De Man, A. P., Van den Bosch, F., \& Elfring, T. (1997). Porter on national and regional competitive advantage. In F. A. J. Van Den Bosch, \& A. P. De Man (Eds.), Perspectives on Strategy: Contributions of Michael E. Porter (pp. 45-59). Boston, MA: Springer US. https://doi.org/10.1007/978-1-4615-6179-8_6

Dögl, C., Holtbrügge, D., \& Schuster, T. (2012). Competitive advantage of German renewable energy firms in India and China: An empirical study based on Porter's diamond. International Journal of Emerging Markets, 7(2), 191-214. https://doi.org/10.1108/17468801211209956

Dunning, J. H. (1992). The competitive advantage of countries and the activities of transnational corporations. Transnational Corporations, 1(1), 135-168.

Dunning, J. H. (1993). Internationalizing Porter's diamond. Management International Review; Wiesbaden, 33(2), 7-15.

Etzkowitz, H., \& Leydesdorff, L. (2000). The dynamics of innovation: From National Systems and "Mode 2" to a Triple Helix of university-industry-government relations. Research Policy, 29(2), 109-123. https://doi.org/10.1016/S0048-7333(99)00055-4

Fainshmidt, S., Smith, A., \& Judge, W. Q. (2016). National competitiveness and Porter's diamond model: The role of MNE penetration and governance quality. Global Strategy Journal, 6(2), 81-104. https://doi.org/10.1002/gsj.1116

Fang, K., Zhou, Y., Wang, S., Ye, R., \& Guo, S. (2018). Assessing national renewable energy competitiveness of the G20: A revised Porter's Diamond Model. Renewable and Sustainable Energy Reviews, 93, 719-731. https://doi.org/10.1016/j.rser.2018.05.011

Ferreira, J. J., Fernandes, C. I., \& Ratten, V. (2016). Entrepreneurship, innovation and competitiveness: What is the connection?. International Journal of Business and Globalisation, 18(1), 73-95. https://doi.org/10.1504/IJBG.2017.10001191

Fortes, V. M. M., Ratten, V., Barcellos, P. F. P., \& Estevão, C. (2018). The study of competitiveness of tourism in Cape Verde: The case of clusters of St. Anthony/São Vicente and Sal/Boavista. International Journal of Business and Globalisation, 20(3), 292-315. https://doi.org/10.1504/IJBG.2018.091506

Foss, N. J. (1996). Research in strategy, economics, and Michael Porter. Journal of Management Studies, 33(1), 1-24. https://doi.org/10.1111/j.1467-6486.1996.tb00796.x

Freeman, C. (2019). History, co-evolution and economic growth. Industrial and Corporate Change, 28(1), 1-44. 
https://doi.org/10.1093/icc/dty075

Grant, R. M. (1991). Porter's 'competitive advantage of nations': An assessment. Strategic Management Journal, 12(7), 535-548. https://doi.org/10.1002/smj.4250120706

Harzing, A.-W., \& Giroud, A. (2014). The competitive advantage of nations: An application to academia. Journal of Informetrics, 8(1), 29-42. https://doi.org/10.1016/j.joi.2013.10.007

Huggins, R., \& Izushi, H. (2015). The competitive advantage of nations: Origins and journey. Competitiveness Review, 25(5), 458-470. https://doi.org/10.1108/CR-06-2015-0044

Iansiti, M., \& Levien, R. (2004). The keystone advantage: What the New Dynamics of Business Ecosystems Mean for Strategy, Innovation, and Sustainability. Boston, MA: Harvard Business School Press.

Jacobs, D., \& de Jong, M. W. (1992). Industrial clusters and the competitiveness of the Netherlands: Empirical results and conceptual issues. De Economist, 140(2), 233-252. https://doi.org/10.1007/BF01460372

Jin, B., \& Moon, H. (2006). The diamond approach to the competitiveness of Korea's apparel industry: Michael Porter and beyond. Journal of Fashion Marketing and Management: An International Journal, 10(2), 195-208. https://doi.org/10.1108/13612020610667504

Kharub, M., \& Sharma, R. (2017). Comparative analyses of competitive advantage using Porter diamond model (the case of MSMEs in Himachal Pradesh). Competitiveness Review, 27(2), 132-160. https://doi.org/10.1108/CR-02-2016-0007

Lipietz, A. (1985). Mirages et miracles: Problèmes de l'industrialisation dans le Tiers Monde. Paris: La Découverte.

Moon, H., \& Peery, N. S. (1995). Competitiveness of product, firm, industry, and nation in a global business. Competitiveness Review, 5(1), 37-43. https://doi.org/10.1108/eb046319

Moon, H., Rugman, A. M., \& Verbeke, A. (1998). A generalized double diamond approach to the global competitiveness of Korea and Singapore. International Business Review, 7(2), 135-150. https://doi.org/10.1016/S0969-5931(98)00002-X

Moon, H., Verbeke, A., \& Rugman, A. M. (1995). The generalized double diamond approach to international competitiveness. Research in Global Strategic Management: Beyond the Diamond, 5, 97-114. https://doi.org/10.1016/S1064-4857(95)05005-1

Moore, J. (1997). The Death of Competition: Leadership and Strategy in the Age of Business Ecosystems. New York: Harper Business.

Narula, R. (1993). Technology, international business and Porter's "Diamond": Synthesizing a dynamic competitive development model. Management International Review, 2(33), 85-107.

Nelson, R. R., Dosi, G., Helfat, C. E., Winter, S. G., Pyka, A., Saviotti, P. P., \& Dopfer, K. (2018). Modern Evolutionary Economics: An Overview. Cambridge: Cambridge University Press. https://doi.org/10.1017/9781108661928

O’ Shaughnessy, N. J. (1996). Michael Porter's competitive advantage revisited. Management Decision, 34(6), 12-20. https://doi.org/10.1108/00251749610145889

Öz, Ö. (2001). Sources of competitive advantage of Turkish construction companies in international markets. Construction Management and Economics, 19(2), 135-144. https://doi.org/10.1080/01446190010009988

Öz, Ö. (2002). Assessing Porter's framework for national advantage: The case of Turkey. Journal of Business Research, 55(6), 509-515. https://doi.org/10.1016/S0148-2963(00)00167-3

Penttinen, R. (1994). Summary of the Critique on Porter's Diamond Model. Porter's Diamond Model Modified to Suit the Finnish Paper and Board Machine Industry. ETLA Discussion Papers (No. 462).

Porter, M. (1990a). The Competitive Advantage of Nations (First Free Press Edition 1990). New York: Free Press. https://doi.org/10.1007/978-1-349-11336-1

Porter, M. (1990b). The competitive advantage of nations. Harvard Business Review: International Business, (March-April 1990 Issue), 73-91.

Porter, M. (2000). Location, competition, and economic development: Local clusters in a global economy. Economic Development Quarterly, 14(1), 15-34. https://doi.org/10.1177/089124240001400105

Rugman, A. M. (1991). Fast forward: Improving Canada's International Competitiveness. Toronto: Kodak Canada. 
Rugman, A. M. (1992). Porter takes the wrong turn. Business Quarterly, 56(3), 59-64.

Rugman, A. M., \& D' Cruz, J. R. (1993). The "Double Diamond" model of international competitiveness: The Canadian experience. MIR: Management International Review, 33, 17-39.

Rugman, A. M., \& Verbeke, A. (1993). How to operationalize porter's diamond of international competitiveness. The International Executive, 35(4), 283-299. https://doi.org/10.1002/tie.5060350403

Smit, A. J. (2010). The competitive advantage of nations: Is Porter's diamond framework a new theory that explains the international competitiveness of countries?. Southern African Business Review, 14(1), 105-130.

Stone, H. B. J., \& Ranchhod, A. (2006). Competitive advantage of a nation in the global arena: A quantitative advancement to Porter's diamond applied to the UK, USA and BRIC nations. Strategic Change, 15(6), 283-284. https://doi.org/10.1002/jsc.770

Stonehouse, G., \& Snowdon, B. (2007). Competitive advantage revisited: Michael Porter on strategy and competitiveness. Journal of Management Inquiry, 16(3), 256-273. https://doi.org/10.1177/1056492607306333

Tavoletti, E., \& te Velde, R. (2008). Cutting Porter's last diamond: Competitive and comparative (dis)advantages in the Dutch flower cluster. Transition Studies Review, 15(2), 303-319. https://doi.org/10.1007/s11300-008-0017-2

Tsiligiris, V. (2018). An adapted Porter diamond model for the evaluation of transnational education host countries. International Journal of Educational Management, 32(2), 210-226. https://doi.org/10.1108/IJEM-03-2017-0076

Van Den Bosch, F. A. J., \& Van Prooijen, A. A. (1992). The competitive advantage of European nations: The impact of national culture - a missing element in porter's analysis?. European Management Journal, 10(2), 173-177. https://doi.org/10.1016/0263-2373(92)90066-D

Vicente, J. (2018). Economics of Clusters. Cham: Springer International Publishing. https://doi.org/10.1007/978-3-319-78870-8

Vlados, Ch. (2004). La dynamique du triangle strategie, technologie et management: L'insertion des entreprises Grecques dans la globalisation (Thèse de doctorat de Sciences Économiques, Université de Paris X-Nanterre). Retrieved from http://www.theses.fr/2004PA100022

Vlados, Ch. (2019). The insertion of Greek firms into globalization: The dynamics of the triangle of strategy, technology and management. Journal of Strategy and Management, 12(3), 347-363. https://doi.org/10.2139/ssrn.3218009

Vlados, Ch., Deniozos, N., Chatzinikolaou, D., \& Demertzis, M. (2018). Towards an evolutionary understanding of the current global socio-economic crisis and restructuring: From a conjunctural to a structural and evolutionary perspective. Research in World Economy, 9(1), 15-33. https://doi.org/10.5430/rwe.v9n1p15

Vlados, Ch., Katimertzopoulos, F., \& Blatsos, I. (2019). Innovation in Stra. Tech. Man (strategy-technology-management) terms. Journal of Entrepreneurship and Business Innovation, 5(2), 1-26. https://doi.org/10.5296/jebi.v5i2.13477

Waheeduzzaman, A. N. M., \& Ryans, J. K. (1996). Definition, perspectives, and understanding of international competitiveness: A quest for a common ground. Competitiveness Review, 6(2), 7-26. https://doi.org/10.1108/eb046333

Waverman, L. (1995). A critical analysis of Porter's framework on the competitive advantage of nations. Research in Global Strategic Management: Beyond the Diamond, 5, 67-95. https://doi.org/10.1016/S1064-4857(95)05004-3

Wonglimpiyarat, J. (2017). The role of government in Porter's Diamond model: Comparative cases of Singapore and Thailand. International Journal of Technology, Policy and Management, 18(1), 73-88. https://doi.org/10.1504/IJTPM.2018.088444

Yetton, P., Craig, J., \& Davis, J. (1992). Are diamonds a country's best friend? A critique of Porter's theory of national competition as applied to Canada, New Zealand and Australia. Australian Journal of Management, 17(1), 89-119. https://doi.org/10.1177/031289629201700105

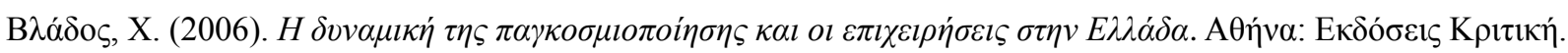

